\title{
POLA LANSKAP PERMUKIMAN TRADISIONAL LAMPUNG PEPADUN: STUDI KASUS TIYUH GEDUNG BATIN
}

\section{TRADITIONAL SETTLEMENT LANDSCAPE PATTERN OF LAMPUNGNESE PEPADUN: TIYUH GEDUNG BATIN CASE STUDY}

\author{
Rian Adetiya Pratiwi ${ }^{1^{*}}$, Andi Gunawan², Aris Munandar ${ }^{3}$ \\ Program Studi Arsitektur Lanskap, Institut Teknologi Sumatera, Indonesia ${ }^{1}$ \\ Departemen Arsitektur Lanskap, Institut Pertanian Bogor, Indonesia2,3 \\ rian.pratiwi@al.itera.ac.id
}

\begin{abstract}
Lampungnese are divided into two indigenous groups, namely Lampung Saibatin and Lampung Pepadun. These two groups are still divided based on their inhabited territories. The objectives of this study are to identify the characteristics and elements that form the traditional settlement landscape pattern of Lampungnese Pepadun community, and to analyze their traditional settlement landscape pattern. This research was conducted in Tiyuh (Kampung) Gedung Batin, Blambangan Umpu District, Way Kanan, Lampung. Data were collected from three important main sources, which are customary texts, traditional leaders interviews, and existing settlement artefacts. The collected data was analyzed using historical approach. The results shows that the constituent elements of the traditional Lampung Pepadun settlement consist of traditional buildings (houses, communal buildings (sesat), as well as places of worship), arable land, rivers, residential roads and burial land. Tiyuh Gedung Batin is arranged in a pattern that extends along the river flow with houses facing each other.
\end{abstract}

Keywords: Content analysis; Lampungnese Pepadun; local culture; settlement pattern; traditional settlement

\section{ABSTRAK}

Masyarakat Lampung terbagi dalam dua kelompok adat, yaitu masyarakat adat Lampung Saibatin dan masyarakat adat Lampung Pepadun. Dua kelompok tersebut masih terbagi berdasarkan wilayah adat yang didiami. Tujuan penelitian adalah mengidentifikasi karakteristik dan elemen-elemen pembentuk lanskap permukiman tradisional masyarakat Lampung Pepadun serta menganalisis pola permukiman tradisional Lampung Pepadun. Penelitian ini dilakukan di Tiyuh (Kampung) Gedung Batin, Kecamatan Blambangan Umpu, Kabupaten Way Kanan. Data dikumpulkan dari tiga sumber utama yang penting, yaitu naskah adat, wawancara tokoh adat, dan artefak permukiman. Data yang terkumpul dianalisis dengan pendekatan kesejarahan. Hasil penelitian menunjukkan elemen-elemen penyusun permukiman tradisional Lampung Pepadun terdiri dari bangunan tradisional (rumah tinggal, bangunan komunal/sesat, tempat ibadah), lahan garapan, sungai, jalan, dan pemakaman. Tiyuh Gedung Batin tersusun dalam pola memanjang mengikuti aliran sungai dengan rumah yang saling berhadapan.

Kata Kunci: Budaya lokal; Lampung Pepadun; permukiman tradisional; pola permukiman

Artikel Masuk

Artikel Diterima
: 30-07-2019

: 17-10-2019 


\section{PENDAHULUAN}

Bentang alam Indonesia secara alami membentuk ragam pola dan perilaku dalam kehidupan kelompok masyarakat dan suku-suku di dalamnya. Masingmasing suku memiliki karakter budaya khas yang tergambar dalam tradisi kedaerahan, aktivitas sosial, serta tata letak hunian dan permukiman dalam kehidupan bermasyarakat. Salah satu suku di Indonesia yang memiliki budaya khas adalah Suku Lampung. Masyarakat Lampung terbagi ke dalam dua kelompok adat, yaitu masyarakat adat Lampung Saibatin dan Lampung Pepadun. Masing-masing kelompok adat tersebut mendiami wilayah berbeda yang tersebar di seluruh Provinsi Lampung. Kelompok masyarakat Lampung Pepadun umumnya mendiami wilayah pedalaman, sementara kelompok masyarakat Lampung Saibatin mendiami wilayah pesisir. Kelompok dengan lingkup adat istiadat yang berbeda, memberi ciri tersendiri bagi lingkungan permukiman masing-masing wilayah adat. Ada hubungan timbal balik antara manusia dan lingkungan. Lanskap menjadi bagian dari manusia yang tinggal di dalamnya begitu pula sebaliknya (Ingold, 1993, hlm. 1).

Undang-Undang Nomor 4 Tahun 1992 tentang Perumahan dan Permukiman menjelaskan bahwa permukiman merupakan lingkungan hidup di luar kawasan lindung, baik kawasan perdesaan maupun perkotaan sebagai lingkungan hunian dan tempat kegiatan yang mendukung perikehidupan dan penghidupan. Permukiman terbentuk dari interaksi manusia dan alam, dengan segala kelengkapannya yang dapat digunakan oleh manusia sebagai tempat tinggal, baik sementara ataupun menetap dalam rangka menyelenggarakan kehidupan. Terbentuknya permukiman dipengaruhi oleh unsur-unsur ekistiknya (Antariksa, 2011, hlm. 1) yakni elemen fisik alami, manusia, masyarakat, naungan, dan jaringan. Elemen fisik alami merupakan sumberdaya geologi, topografi, hidrologi, vegetasi, hewan, dan iklim. Elemen manusia memiliki kebutuhan ruang hidup, biologis, persepsi, emosional, dan nilai kehidupan. Masyarakat termasuk di dalamnya terdapat komposisi dan kepadatan penduduk, stratifikasi masyarakat, budaya yang terbentuk di dalamnya, pertumbuhan ekonomi, tingkat pendidikan, kesehatan, dan kesejahteraan, serta aturan hukum dan administrasi. Naungan dalam permukiman dapat berupa rumah, pelayanan masyarakat, pusat aktivitas dan perdagangan, pusat rekreasi, pusat kegiatan ekonomi dan industri, dan pusat pergerakan yang mendukung usaha hidup masyarakat. Jaringan dalam permukiman dapat berupa sistem jaringan air dan listrik, sistem transportasi, sistem komunikasi, serta sistem pembuangan limbah. Secara kronologis kelima elemen ekistik tersebut membentuk lingkungan permukiman.

Berdasarkan pengertian tersebut, maka pada dasarnya suatu permukiman terdiri dari isi (content), yaitu manusia baik secara individual maupun dalam masyarakat dan wadah (container), yaitu lingkungan fisik permukiman (Doxiadis, 1970, hlm. 3). Permukiman tradisional merupakan salah satu pembentuk identitas suatu masyarakat tradisional dan merupakan tempat yang masih memegang nilainilai adat dan budaya (Crysler, 2000, hlm. 55). Permukiman tradisional adalah kawasan yang memberikan ciri atau identitas bagi lingkungannya. Tata ruang suatu permukiman tradisional umumnya tersusun dari bangunan dan ruang di sekitarnya, tatanan ruang, serta pola dari komposisinya (Krisna dkk., 2005, hlm. 126). 
Pola lanskap permukiman tradisional suku-suku di Indonesia belum banyak diteliti, salah satunya adalah permukiman masyarakat suku Pepadun Lampung. Lebih jauh lagi bahwa penelitian tidak hanya terbatas pada artefak permukiman yang masih ada, tapi juga didasarkan pada informasi budaya baik berupa naskah adat maupun informasi lisan para tokoh adat. Provinsi Lampung sebagai salah satu Wilayah Pengembangan Strategis Sumatera mengalami pembangunan infrastruktur yang sangat pesat. Pembangunan yang terjadi di Provinsi Lampung dapat memengaruhi eksistensi permukiman-permukiman tradisional yang ada. Tindakan pelestarian yang sesuai diperlukan untuk mempertahankan nilai-nilai budaya yang ada pada permukiman-permukiman tradisional Lampung.

Tujuan dari penelitian ini adalah mengidentifikasi karakteristik dan elemen-elemen pembentuk lanskap permukiman tradisional masyarakat Lampung Pepadun dan menganalisis pola permukiman tradisional Lampung Pepadun yang seharusnya ada ditinjau dari sudut pandang budaya serta faktorfaktor yang memengaruhinya. Hasil dari penelitian ini diharapkan dapat memberi gambaran mengenai permukiman tradisional Lampung dalam bentuk konsep pola permukiman beserta seluruh elemen penting pembentuk permukiman. Konsep tersebut juga diharapkan dapat digunakan untuk mengangkat dan memperkuat nilai-nilai budaya Lampung, sebagai usaha pelestarian permukimanpermukiman tradisional di Provinsi Lampung.

\section{METODE}

Penelitian kualitatif ini menggunakan pendekatan kesejarahan untuk menghimpun data masa lampau, mendeskripsikan dan menganalisa fakta yang diperoleh, serta menyajikan sintesis yang diperoleh dari penelusuran sejarah (Sulasman, 2014, hlm. 73). Pemilihan lokasi penelitian dilakukan secara sengaja agar mendapatkan makna dan esensi penelitian dari kelompok sampel yang kecil (Miles dkk., 2007, hlm. 47). Tiyuh Gedung Batin yang berada di Kecamatan Blambangan Umpu, Kabupaten Way Kanan, Provinsi Lampung, dipilih sebagai lokasi penelitian didasarkan atas pertimbangan kualitas rumah-rumah tradisional yang relatif masih murni serta aktivitas budaya yang masih dilakukan oleh masyarakatnya (Gambar 1).
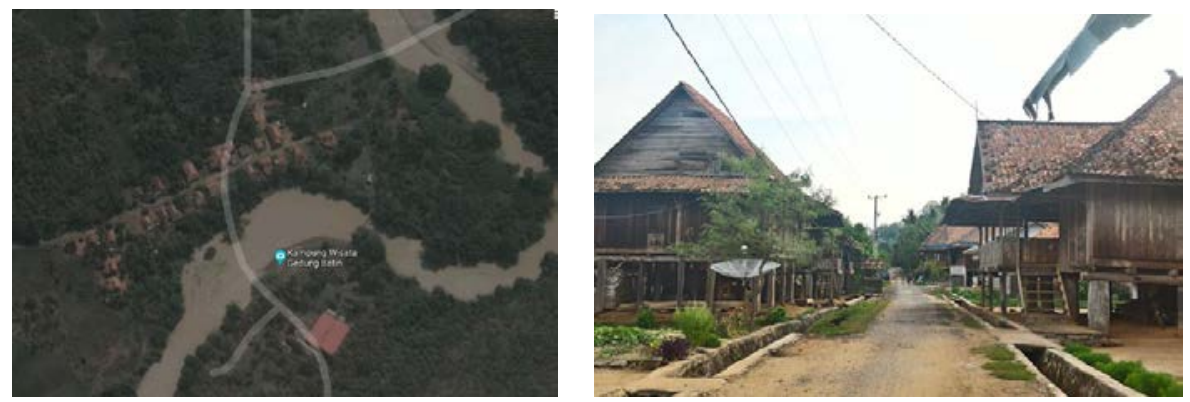

Gambar 1. Lokasi Penelitian

(Sumber: maps.google.co.id) 


\section{Pengumpulan Data}

Informasi yang dihimpun bersumber dari (1) naskah adat, (2) wawancara tokoh adat, dan (3) kondisi eksisting permukiman. Naskah adat yang dijadikan sebagai sumber adalah salinan dari Kitab Kuntara Raja Niti yang didapat dari Penengahan dan Bumi Jawa Sukadana, Ketaro Abung, serta Buku Handak II. Jenis data yang dihimpun antara lain adalah karakteristik permukiman, elemen-elemen pembentuk permukiman, pola permukiman, serta faktor pembentuk pola permukiman.

Berdasarkan strukturnya, pendekatan wawancara tertutup akan memberikan hasil yang lebih rinci karena dipandu oleh pertanyaan yang terarah (Djaelani, 2014, hlm. 87). Pendekatan ini dipilih karena peneliti ingin menggali lebih dalam terkait aktivitas budaya yang berkaitan dengan spasial ruang. Wawancara dilakukan terhadap tokoh adat tiyuh secara mendalam dengan pendekatan snowball interview dan menggunakan panduan pertanyaan yang berkaitan dengan data/informasi yang ingin dicari. Untuk memverifikasi hasil eksplorasi dari naskah adat dan wawancara tokoh adat, dilakukan kunjungan lapang pada lokasi permukiman. Pengukuran dan pemetaan permukiman dilakukan untuk mengetahui elemen dan pola permukiman eksisting.

\section{Analisis}

Analisis terhadap elemen penyusun permukiman tradisional masyarakat Lampung Pepadun dilakukan dengan mengkombinasikan pendekatan kualitatif deskriptif dengan interpretasi sejarah tertulis, dalam hal ini yang tertulis di dalam naskah adat. Tahapan penentuan elemen penyusun permukiman tradisional masyarakat Lampung Pepadun dilakukan dengan mengumpulkan data, mengidentifikasi dan menyeleksi data, serta memilih kata kunci spesifik untuk menentukan elemen-elemen pembentuk permukiman tradisional Lampung Pepadun (Lune dkk., 2017, hlm. 184).

Kata kunci yang dicari di dalam naskah adat Kitab Kuntara Raja Niti yang didapat dari Penengahan dan Bumi Jawa Sukadana, Ketaro Abung, serta Buku Handak II dipilih dari hasil pengumpulan data sekunder dari buku-buku, pustaka umum, serta penelitian terdahulu yang terkait dengan budaya dan arsitektur tradisional Lampung. Kata kunci sebagai unit analisis yang dicari di dalam naskah-naskah adat di arahan secara spesifik, meliputi elemen-elemen pembentuk permukiman yang terkait dengan tema bangunan tradisional dan lingkungan permukiman, serta tata cara dan aturan hidup bermasyarakat dalam suatu permukiman tradisional Lampung.

Analisis untuk menentukan elemen-elemen penting pembentuk lanskap permukiman tradisional Lampung di Tiyuh Gedung Batin dilakukan dengan membandingkan hasil studi pustaka dari buku-buku serta penelitian terdahulu yang terkait dengan budaya dan arsitektur tradisional Lampung dengan kata kunci elemen-elemen permukiman yang didapat dari naskah adat. Validasi dilakukan dengan membandingkan elemen-elemen penting yang didapat dari studi pustaka dan naskah adat dengan penuturan dari tokoh adat untuk menentukan elemen-elemen pentik pembentuk permukiman yang dinyatakan pernah ada atau harus ada di dalam suatu tiyuh menurut budaya. 


\section{HASIL PENELITIAN}

\section{Karakteristik Permukiman Tiyuh Gedung Batin}

Masyarakat Lampung Way Kanan termasuk ke dalam kelompok masyarakat adat Pepadun. Kelompok masyarakat Way Kanan juga dikenal sebagai warga Buai Lima, yang berarti lima keturunan. Lima keturunan tersebut diantaranya adalah Buai Bahuga, Buai Berasakti, Buai Semenguk, Buai Baradatu, dan Buai Pemuka. Masyarakat Tiyuh Gedung Batin termasuk ke dalam golongan Buai Semenguk. Seperti masyarakat Lampung pada umumnya, sistem kekerabatan dalam masyarakat Tiyuh Gedung Batin juga menganut konsep kepunyimbangan. Punyimbang secara akar kata berasal dari kata pun dan nyimbang. Pun berarti yang dihormati, sementara nyimbang berarti mewarisi, jadi punyimbang berarti seseorang yang dihormati karena asal usul keturunannya. Status kepunyimbangan ini diteruskan secara turun-temurun di dalam keluarga kepada anak laki-laki tertua. Gelar punyimbang sangat dihormati karena perannya dalam proses pengambilan keputusan di dalam ranah adat (Hadikusuma, 1989).

Lanskap permukiman Tiyuh Gedung Batin saat ini dikelilingi oleh perkebunan karet. Berdasarkan informasi dari tokoh adat, sebelum menetap pada posisinya saat ini, Tiyuh Gedung Batin telah mengalami dua kali perpindahan dikaren akan naiknya level muka air sehingga mengganggu aktivitas hidup di permukiman. Zona yang secara langsung berbatasan dengan badan air lebih sensitif terhadap perubahan lingkungan (Pinke dkk., 2016, hlm. 1), sedikit saja perubahan yang terjadi pada lingkungan seperti kenaikan level muka air dapat mengakibatkan masyarakat harus berpindah dari zona tersebut. Ketika pertama kali dipindahkan ke lokasi saat ini, rumah-rumah di tiyuh tuha (kampung tua) masih berjumlah puluhan dengan rumah yang bersusun dua lapis mengikuti aliran sungai.
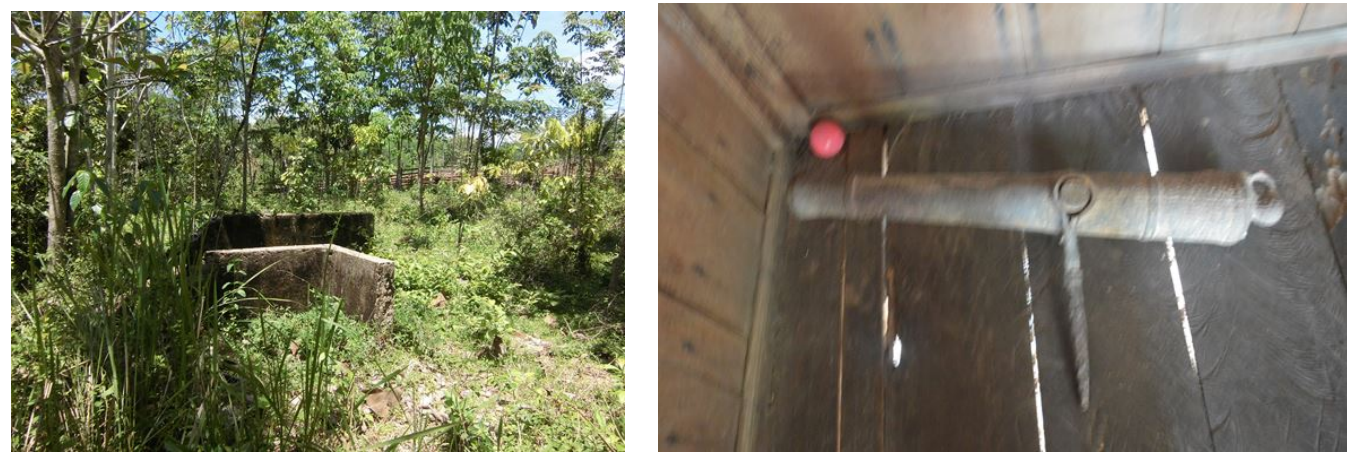

Gambar 2. Peninggalan Belanda di Tiyuh Gedung Batin: Reruntuhan Kantor Belanda (kiri) dan Meriam Peninggalan Belanda (kanan)

(Sumber : Dibyo Harsono, 2016)

Seiring perkembangan zaman dan karena desakan ekonomi, masyarakat banyak yang pindah ke kota dan menjual rumahnya sehingga kelompok rumahrumah di tiyuh berkurang menjadi satu lajur memanjang. Rumah-rumah yang ditinggalkan sebagian besar rusak dan dibongkar, ada pula rumah yang dibongkar dan dijual kayunya. Saat ini rumah tua yang tersisa di tiyuh hanya sejumlah sepuluh unit. Tiyuh dibentuk oleh rumah-rumah tua dan rumah baru di 
sekitarnya, sebagian kebun warga di sekitar rumah, jalan utama yang memanjang membelah tiyuh, serta sungai Way Besai. Menurut penuturan tokoh adat, dahulu tiyuh merupakan tempat yang ramai menjadi persinggahan pedagang karena sempat menjadi salah satu tempat yang diduduki Belanda. Meskipun demikian, tokoh adat menegaskan jika bangsa Belanda tidak menjajah melainkan hanya menetap dan sempat menjadikan tiyuh sebagai permukiman percontohan tradisional Lampung.Bukti kedatangan bangsa Belanda ke Tiyuh Gedung Batin dapat dilihat pada Gambar 2.

Tiyuh Gedung Batin merupakan kampung lebuh (kerajaan) di mana pada awal mula berdirinya tiyuh ada tiga lebuh yang memimpin di tiyuh yakni Lebuh Bujung, Lebuh Tengah, dan Lebuh Talang. Seiring berjalannya waktu, Lebuh Bujung membagi keturunannya untuk membentuk Lebuh Bujung Unggak. Masing-masing lebuh memiliki rumah adat dan punyimbang marga (pemimpin marga). Saat ini, yang tersisa di Tiyuh gedung Batin hanya punyimbang dari Lebuh Bujung dan Lebuh Tengah, sementara punyimbang dari Lebuh Talang dan Lebuh Bujung Unggak sudah tidak tinggal di Tiyuh Gedung Batin. Rumah punyimbang dari dua lebuh yang tersisa masih berdiri hingga saat ini, yakni Nuwa Tantan Gumanti dari Lebuh Tengah dan Nuwa Benawa dari Lebuh Bujung (Gambar 3). Punyimbang marga berperan mengayomi seluruh masyarakatnya. Meskipun saat ini masyarakat tinggal berbaur antar lebuh, namun mereka tetap harus patuh dengan lebuh masingmasing. Anggota masing-masing lebuh harus selalu siap jika punyimbang mereka memerlukan bantuan. Adanya pengelompokan lebuh ini tidak memecah masyarakat menjadi kelompok-kelompok kecil.
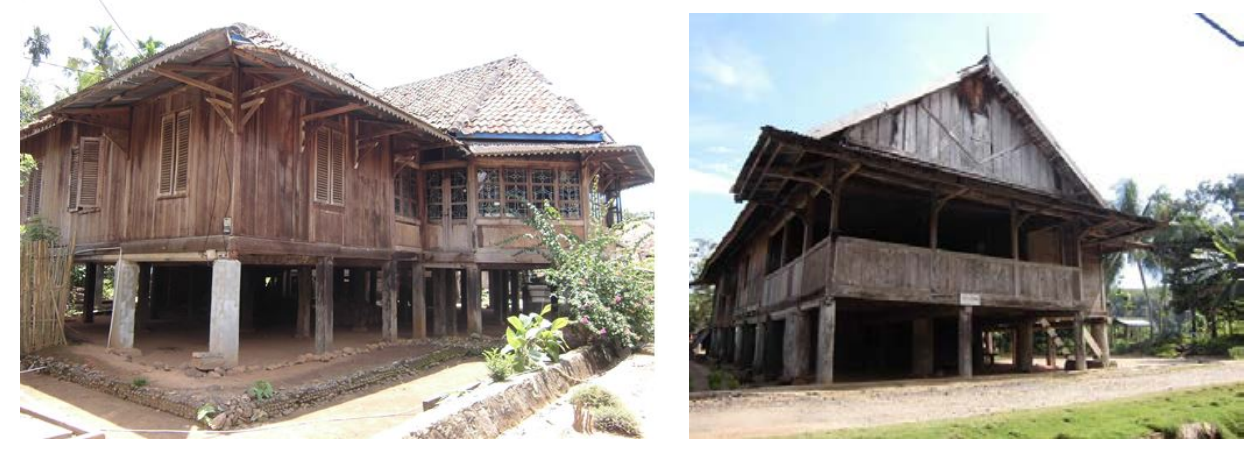

Gambar 3. Rumah Punyimbang di Tiyuh Gedung Batin: Nuwa Tantan Gumanti (kiri) dan Nuwa Benawa (kanan)

(Sumber :Penulis)

\section{Elemen Pembentuk Permukiman Tradisional Lampung Pepadun}

Tiyuh Gedung Batin, seperti halnya permukiman tradisional Lampung Pepadun pada umumnya terbentuk oleh elemen-elemen permukiman yang memiliki aturan tata letak, orientasi, dan susunan tertentu yang memberi karakter khas pada permukiman. Berdasarkan hasil penelusuran data dari literatur terkait, naskah adat, serta wawancara tokoh adat, peneliti mengelompokkan tiga komponen utama pembentuk permukiman tradisional Lampung yaitu bangunan tradisional rumah tinggal, bangunan komunal, serta elemen-elemen pendukung 
yang ada di lingkungan permukiman. Elemen bangunan tradisional rumah tinggal dijelaskan pada Tabel 1.

Tabel 1. Elemen pembentuk permukiman : Bangunan tradisional rumah tinggal berdasarkan naskah adat, wawancara, dan pustaka umum

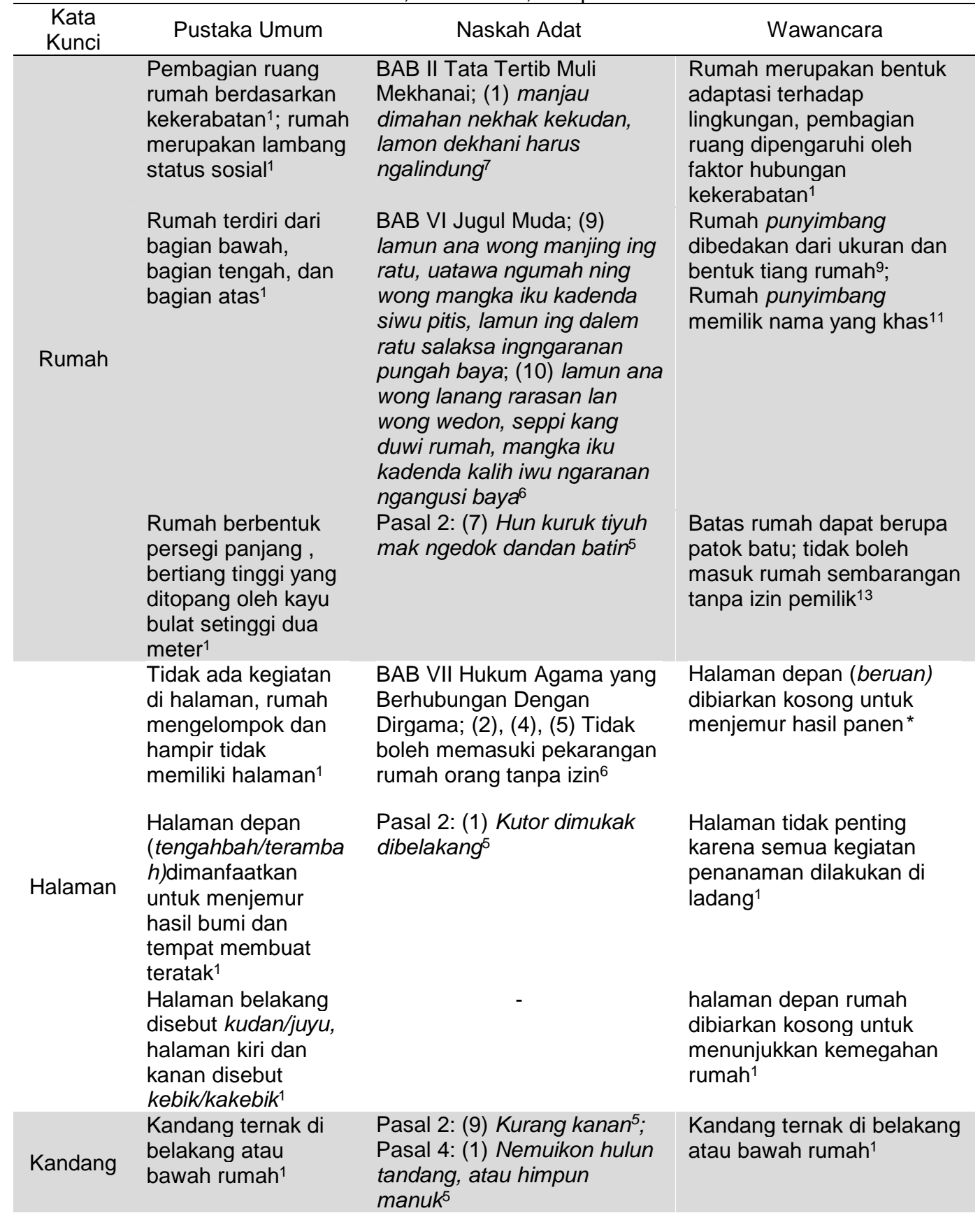




\begin{tabular}{|c|c|c|c|}
\hline $\begin{array}{l}\text { Kata } \\
\text { Kunci }\end{array}$ & Pustaka Umum & Naskah Adat & Wawancara \\
\hline Tanaman & - & $\begin{array}{l}\text { Pasal 3: (5) Tanam tumbuh } \\
\text { selamat5 }^{5}\end{array}$ & $\begin{array}{l}\text { tanaman yang ditanam } \\
\text { adalah tanaman yang } \\
\text { bermanfaat }^{1} \\
\text { Batas rumah (langen) } \\
\text { biasanya berupa tanaman } \\
\text { jarak kuto (jarak pagar); } \\
\text { penanda batas ujung rumah } \\
\text { bisa menggunakan kayu } \\
\text { labeu (pohon maja* } \\
\text { Buah bernung umum } \\
\text { dipakai untuk ambil air } \\
\end{array}$ \\
\hline
\end{tabular}

Sumber:

${ }^{1}$ (Pratiwi \& Gunawan, 2017); 2 (Proyek Penelitian dan Pencatatan Kebudayaan Daerah, 1978); ${ }^{3}$ (Wahyuningsih, 2011); ${ }^{4}$ Rusdi, Arifin, Suparno, Indra, \& Zaini, 1986); ${ }^{5}$ Kuntara Raja Niti (Bumi Jawa Sukadana); ${ }^{6}$ Kuntara Raja Niti (Penengahan); ${ }^{7}$ Buku Handak II; ${ }^{8}$ Ketaro Abung; ${ }^{9}$ Raden Supardi GIr. Raden Ustad Marga; ${ }^{10}$ Buya Wahid GIr. Tuan Kebudayaan; ${ }^{11}$ Ali Bakri GIr. Kilat Mas; ${ }^{12}$ Firmansyah; ${ }^{13}$ Mat Amin

\section{Rumah tinggal}

Bangunan rumah tradisional Lampung berupa rumah panggung dengan tiang setinggi dua sampai tiga meter, berbentuk segi empat atau persegi panjang. Bagian rumah yang pendek atau lebar biasanya menghadap ke jalan raya, sedangkan bagian panjangnya membujur ke belakang (ijung kudan/juyu/buri) (Proyek Penelitian dan Pencatatan Kebudayaan Daerah, 1978, hlm. 146). Rumah secara vertikal dibagi menjadi tiga bagian yakni bah lamban (bawah rumah), khesi (tengah rumah) dan panggakh (atas rumah). Secara simbolis bagian bawah merupakan tempat yang kotor, bagian tengah merupakan tempat aktivitas hidup, sedangkan bagian atas merupakan tempat suci di mana pada beberapa kampung masih ditemukan pemilik yang menyimpan pamanohan (benda pusaka) di bagian atas rumah (Pratiwi dkk., 2017, hlm.3). Pembagian ruang dalam rumah tradisional Lampung dipengaruhi oleh faktor hubungan kekerabatan atau nilai-nilai tradisi yang berlaku antar anggota keluarga dan kerabat. Rumah juga merupakan perlambang dari status sosial pemiliknya terutama pada masyarakat Lampung Pepadun yang terkenal dengan nilai demokratisnya.

Rumah juga merupakan tempat terjadinya aktivitas sosial bagi penghuninya, seperti yang tertera di Tabel 1. Saat manjau muli (berkunjung ke rumah gadis), bujang gadis bertemu di bagian belakang rumah, dan bujang diharuskan memakai tutup kepala. Rumah tinggal umumnya tidak memiliki batas yang nyata dengan rumah tetangga, sehingga antar rumah di dalam suatu permukiman tradisional seolah-olah menyatu. Hal ini terjadi karena sebagian besar masyarakat dalam suatu tiyuh merupakan saudara atau kerabat dekat. Meskipun demikian, seseorang tidak dapat secara bebas memasuki rumah atau pekarangan milik orang lain. Hal ini diatur dalam Kitab Kuntara Raja Niti (Penengahan) yakni dalam Bab VI Jugul Muda Pasal 9 dan 10 yang berisi tentang larangan memasuki rumah orang lain tanpa izin serta larangan mendatangi wanita yang sendirian di rumah. Selain itu, pada Bab VII Hukum Agama yang 
Berhubungan dengan Dirgama pada Pasal 2, 4, dan 5 juga disebutkan larangan memasuki pekarangan milik orang lain tanpa izin (Tabel 1).

Pada Kitab Kuntara Raja Niti (Bumi Jawa Sukadana) disebutkan juga beberapa aturan terkait rumah tinggal yakni pada Pasal 2 Maluni tiyuh 10 perkara ayat 1 mengenai kewajiban menjaga kebersihan di sekitar rumah, serta pada ayat 7 mengenai keharusan akan dibedakannya rumah punyimbang dan rumah masyarakat biasa yang berbunyi "hun kuruk tiyuh mak ngedok dandan batin". Maksud dari aturan ini adalah suatu tiyuh akan tercela apabila tidak terlihat perbedaan antara rumah punyimbang dan rumah masyarakat biasa. Perbedaan antara rumah punyimbang dan rumah masyarakat biasa umumnya terlihat dari bahan yang digunakan dan ukuran rumah.

Rumah punyimbang pada Tiyuh Gedung Batin berukuran lebih besar dari rumah biasa, dan menggunakan balok kayu bulat sebagai tiang penyangganya (Gambar 4). Selain itu, ada pula aturan yang mengharuskan masyarakat tiyuh untuk produktif dalam mengolah ladangnya. Hal ini tertulis dalam aturan dari Kitab Kuntara Raja Niti Bumi Jawa Sukadana, pada pasal 3 Senangni negeri 6 perkara (Senangnya negeri 6 perkara) ayat 5 yang berbunyi "Tanam tumbuh selamat"yang artinya masyarakat akan hidup sejahtera jika tanaman (produksi) yang mereka usahakan dapat memenuhi kebutuhan hidup sehari-hari.

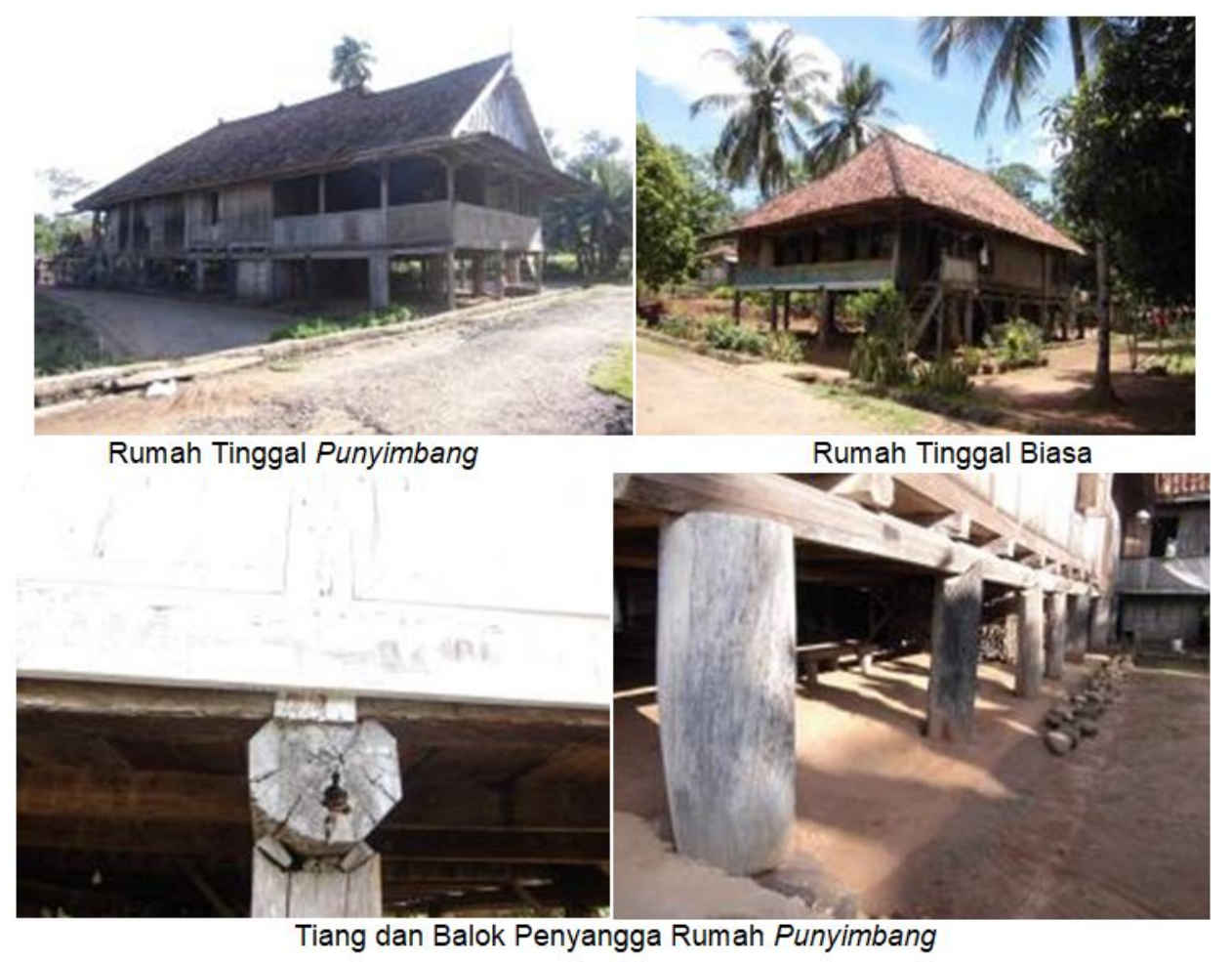

Gambar 4 Perbedaan Rumah Tinggal Punyimbang dan Rumah Tinggal Biasa (Sumber :Penulis) 


\section{Bangunan komunal}

Elemen penting lainnya dalam permukiman tradisional Lampung adalah bangunan tradisional komunal yaitu sesat, mesigit, dan penyembahyangan (Tabel 2). Sesat (balai adat) merupakan bangunan tempat bermusyawarah yang dipergunakan untuk hal-hal yang berhubungan dengan adat (Rusdi dkk., 1986: 66). Keberadaan sesat dalam suatu tiyuh sangat penting karena bangunan ini merupakan tempat utama terjadinya berbagai acara dan musyawarah adat. Hal ini dipertegas dengan aturan yang tertulis pada Kitab Kuntara raja Niti (Bumi Jawa Sukadana), Pasal 2 Maluni Tiyuh 10 Perkara ayat 2. Ayat ini menjelaskan bahwa suatu tiyuh akan tercela apabila tidak memiliki sesat atau balai adat sebagai tempat bermusyawarah.

Tabel 2. Elemen pembentuk permukiman : Bangunan komunal berdasarkan naskah adat, wawancara, dan pustaka umum

\begin{tabular}{|c|c|c|c|}
\hline Kata Kunci & Pustaka Umum & Manuskrip & Wawancara \\
\hline \multirow{3}{*}{ Sesat } & $\begin{array}{l}\text { Sesat atau balai adat } \\
\text { umumnya akan terletak } \\
\text { di seberang masjid }{ }^{4}\end{array}$ & Pasal 2 (3) Mak busesat ${ }^{5}$ & \multirow{3}{*}{$\begin{array}{l}\text { Sesat harus } \\
\text { berada di tengah } \\
\text { tiyuh }^{9}, 11\end{array}$} \\
\hline & \multirow[t]{2}{*}{$\begin{array}{l}\text { Bangunan tempat } \\
\text { bermusyawarah adat } \\
\text { disebut dengan sesat } \\
\text { atau bantaian }{ }^{1}\end{array}$} & $\begin{array}{l}\text { BAB VI Negakko Kedudukan } \\
\text { Dalam Adat; (50) Membahas } \\
\text { persyaratan menegakkan rumah } \\
\text { adat; (51) Syarat menutup rumah } \\
\text { adat sementara; (52) Syarat } \\
\text { membuka kembali rumah adat; } \\
\text { (53) Syarat memindahkan rumah } \\
\text { adat sementara; (54) Syarat } \\
\text { memindahkan rumah adat ke } \\
\text { kampung lain } 7\end{array}$ & \\
\hline & & $\begin{array}{l}\text { Passal } 2 A ; \text {..."Apabila mau } \\
\text { memiliki titi disesat } \\
\text { (Jembatan=tetayan) disesat } \\
\text { dikeluarkan biaya } 2 \text { ekor kerbau } \\
\text { dan (dana) } 24 " . . .8\end{array}$ & \\
\hline \multirow{2}{*}{ Mesigit } & \multirow{2}{*}{$\begin{array}{l}\text { Tempat ibadah } \\
\text { umumnya disebut } \\
\text { mesigit dan surau/rang } \\
\text { ngaji/pok ngajei }{ }^{4}\end{array}$} & $\begin{array}{l}\text { Pasal 2: (4) Mak bulanggar atau } \\
\text { musigit; (6) Mak bugeduk }{ }^{1}\end{array}$ & \multirow{2}{*}{$\begin{array}{l}\text { Masjid tua } \\
\text { dahulu berada di } \\
\text { depan tiyuh, } \\
\text { dekat dengan } \\
\text { sesat }^{11}\end{array}$} \\
\hline & & $\begin{array}{l}\text { Pasal 3: (6) Penghulu ni } \\
\text { pulanggar }^{5}\end{array}$ & \\
\hline $\begin{array}{l}\text { Penyembah- } \\
\text { yangan }\end{array}$ & $\begin{array}{l}\text { Penyembahyangan } \\
\text { berukuran lebih kecil } \\
\text { berada dekat pekkalan } \\
\text { mandi }^{4}\end{array}$ & - & - \\
\hline
\end{tabular}

1(Pratiwi \& Gunawan, 2017); ${ }^{2}$ (Proyek Penelitian dan Pencatatan Kebudayaan Daerah, 1978); ${ }^{3}$ (Wahyuningsih, 2011); ${ }^{4}$ (Rusdi et al., 1986); ${ }^{5}$ Kuntara Raja Niti (Bumi Jawa Sukadana); ${ }^{6}$ Kuntara Raja Niti (Penengahan); ${ }^{7}$ Buku Handak II; ${ }^{8}$ Ketaro Abung; ${ }^{9}$ Raden Supardi GIr. Raden Ustad Marga; ${ }^{10}$ Buya Wahid Glr. Tuan Kebudayaan; ${ }^{11}$ Ali Bakri Glr. Kilat Mas; ${ }^{12}$ Firmansyah; ${ }^{13}$ Mat Amin

Buku Handak II juga menjelaskan masalah ini secara lebih rinci dalam beberapa pasal (pasal 50-54) dari syarat pembuatan mahan adat (rumah adat) permanen hingga pemindahan mahan adat ke tiyuh lain. Selain aturan-aturan yang telah dijelaskan di atas, Ketaro Abung Pasal 2A juga menyebutkan satu aturan 
terkait sesat yakni apabila ingin menambahkan jembatan di dalam sesat disyaratkan untuk memotong dua ekor kerbau. Berdasarkan penjabaran dari ketiga naskah adat, sudah sangat jelas bahwa keberadaan sesat atau mahan adat dalam suatu tiyuh sangat penting.

Selain sesat, bangunan komunal penting lainnya adalah tempat ibadah atau rumah ibadah. Pentingnya keberadaan mesigit (masjid) atau penyembahyangan (langgar) dalam tiyuh disebutkan dalam Kitab Kuntara Raja Niti (Bumi Jawa Sukadana), Pasal 2 Maluni Tiyuh 10 Perkara pada ayat 4 dan 6. Kedua ayat ini secara berurutan menegaskan bahwa suatu tiyuh akan celaka apabila tidak mak bulanggar mak bumusigit dan mak bugeduk. Kampung akan tercela apabila tidak memiliki rumah ibadah langgar atau masjid, sehingga masyarakatnya tidak pernah salat berjamaah sebagai bentuk kerukunan beragama. Mak bugeduk artinya adalah meskipun ada masjid atau langgar namun tidak memiliki bedug, kampung tersebut tetap akan celaka karena tidak adanya pengingat untuk salat. Aturan lain yang menegaskan pentingnya keberadaan masjid di dalam tiyuh adalah pada Pasal 3 Senangni negeri 6 perkara pada ayat 6 yang menyebutkan bahwa suatu tiyuh akan sejahtera apabila punyimbangnya rajin ke masjid. Selain masjid dan langgar, ada pula tempat ibadah yang berukuran lebih kecil dan biasanya terletak di dekat pemandian atau biasa disebut sebagai penyembahyangan. Saat ini di Tiyuh Gedung Batin sudah tidak dapat ditemukan lagi bangunan sesat dan masjid yang asli. Sesat yang asli sudah tidak ada di tiyuh sejak perpindahan terjadi. Demikian pula dengan mesigit atau penyembahyangan, masjid yang ada di Tiyuh Gedung Batin saat ini sudah berupa bangunan permanen. Ilustrasi sesat dan masjid dapat dilihat pada Gambar 5.

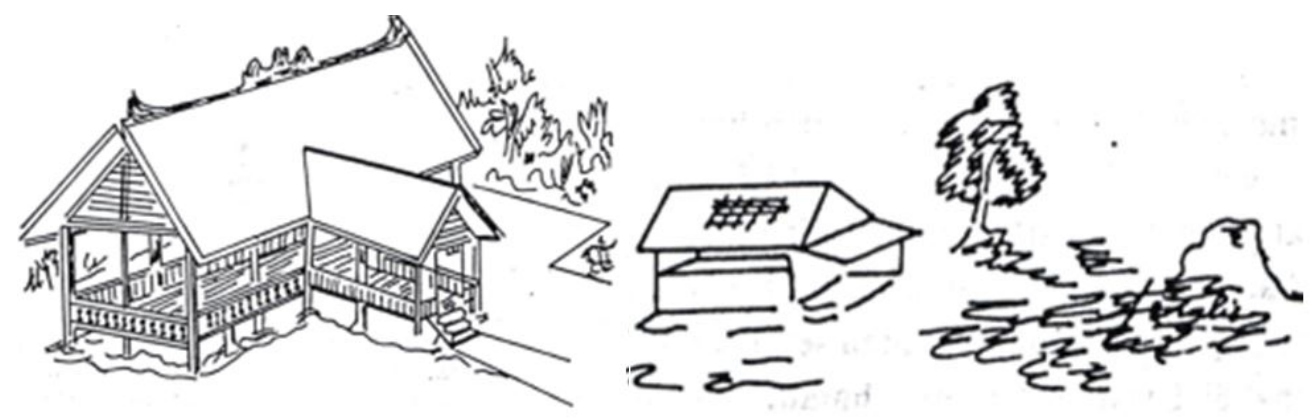

Gambar 5. Bangunan Komunal Sesat (kiri) dan Bangunan Komunal Penyembahyangan (kanan)

(Sumber: Rusdi, Arifin, Suparno, Indra, \& Zaini, 1986: 65-67)

\section{Lingkungan permukiman}

Lingkungan sekitar juga turut membentuk karakter permukiman tradisional. Informasi mengenai peran lingkungan sekitar permukiman sebagai pembentuk pola permukiman tradisional dapat dilihat pada Tabel 3. Sebagian besar masyarakat Tiyuh Gedung Batin bermata pencaharian sebagai petani. Masyarakat Tiyuh Gedung Batin tidak melakukan kegiatan becocok tanam di sekitar rumah. Ladang dan kebun mereka letaknya terpisah dan jauh dari 
permukiman, berada di sisi lain dari sungai. Aturan-aturan terkait usaha di ladang beberapa kali disebutkan dalam Kitab Kuntara Raja Niti (Bumi Jawa Sukadana), yakni pada pasal 2, 3, dan 4. Pasal 2 ayat 9 menegaskan bahwa masyarakat harus senantiasa mengolah ladang dan kebun sehingga kebutuhan pangan dapat dipenuhi secara swadaya. Demikian pula pada Pasal 3 ayat 5 yang menyebutkan agar tanaman tumbuh subur dan masyarakat bahagia serta tercukupi kebutuhannya jika selalu giat berusaha bertani. Hal serupa juga dijelaskan pada Pasal 4 ayat 1, yakni suatu tiyuh akan berbahagia jika banyak orang dari tiyuh lain yang datang dan mencari hasil bumi ke tiyuh tersebut. Tingginya frekuensi kegiatan di ladang baik itu kegiatan bercocok tanam atau saat menunggu panen, masyarakat akan membuat bangunan sementara.

Selain mengenai kebun dan ladang, aturan penting lain yang disebut di dalam naskah adat adalah aturan mengenai kewajiban menjaga sungai. Sungai sudah menjadi bagian besar dalam kehidupan masyarakat Tiyuh Gedung Batin dan masyarakat Lampung pada umumnya. Aturan mengenai kewajiban menjaga sungai disebutkan dalam Kitab Kuntara Raja Niti (Bumi Jawa Sukadana) Pasal 4 Ganjaran humbul 5 perkara ayat 2 dan 3. Maksud dari pasal 4 ayat 2 adalah pengairan (sungai) yang mengalir mengandung banyak ikan jika sungai dilestarikan. Selain akan menghasilkan ikan untuk dikonsumsi, pasal 4 ayat 3 menggambarkan jika sungai dijaga dengan baik, sungai menjadi bersih, pemandian yang teratur dengan air yang mengalir deras menggambarkan kemakmuran suatu tiyuh.

Salah satu penanda permukiman tradisional Lampung adalah dengan adanya pemandian atau pakkalan mandi. Pakkalan mandi ragah (pangkalan mandi pria) dan pakkalan mandi sebai (pangkalan mandi wanita) umumnya terpisah. Meskipun masyarakat masih melakukan kegiatan mandi di sungai, namun pakkalan mandi saat ini tidak ditemukan lagi di Tiyuh Gedung Batin. Masyarakat biasanya akan langsung masuk ke sungai untuk mandi tanpa melalui lanting karena air sungai sudah dangkal. Adapun bentuk dari pakkalan mandi dan lanting dapat dilihat pada Gambar 6. Aturan mengenai pakkalan mandi dijelaskan di dalam Kedua Kitab Kuntara Raja Niti (Bumi Jawa Sukadana), Pasal 2 Maluni tiyuh 10 perkara ayat 1 . Maksud dari penggalan ayat tersebut adalah, suatu tiyuh akan malu dan tercela apabila di dalamnya tidak ada pakkalan ragah dan pakalan sebai dan pemandian yang bercampur baur.

Tabel 3. Elemen pembentuk permukiman : Lingkungan Permukiman berdasarkan naskah adat, wawancara, dan pustaka umum

\begin{tabular}{|c|c|c|c|}
\hline $\begin{array}{l}\text { Kata } \\
\text { Kunci }\end{array}$ & Pustaka Umum & Manuskrip & Wawancara \\
\hline $\begin{array}{l}\text { Kebun } \\
\text { dan } \\
\text { Ladang }\end{array}$ & $\begin{array}{l}\text { Kebun berada jauh di luar } \\
\text { kampung }^{1}\end{array}$ & $\begin{array}{l}\text { Pasal 3: (5) Tanam tumbuh } \\
\text { selamat }{ }^{5} \text {; Ganjaran humbul } \\
5 \text { perkara: Nemuiko hulun } \\
\text { tandang, maupun himpun } \\
\text { manuk }{ }^{5} \text {; pasal } 2 \text { (10) } \\
\text { Maluni tiyuh } 10 \text { perkara: } \\
\text { kughang kanan }^{5}\end{array}$ & $\begin{array}{l}\text { Tanaman tidak } \\
\text { ditanam di sekitar } \\
\text { rumah, melainkan di } \\
\text { kebon }^{1}\end{array}$ \\
\hline $\begin{array}{l}\text { Pakkalan } \\
\text { mandi }\end{array}$ & $\begin{array}{l}\text { Permukiman terletak di } \\
\text { tepi sungai atau di dekat }\end{array}$ & $\begin{array}{l}\text { Pasal 2: (2) Mak } \\
\text { bupakkalan ragah }\end{array}$ & $\begin{array}{l}\text { Rumah tradisional } \\
\text { dahulu menghadap }\end{array}$ \\
\hline
\end{tabular}




\begin{tabular}{|c|c|c|c|}
\hline $\begin{array}{l}\text { Kata } \\
\text { Kunci }\end{array}$ & Pustaka Umum & Manuskrip & Wawancara \\
\hline & $\begin{array}{l}\text { sungai, bentuk kampung } \\
\text { memanjang akibat adanya } \\
\text { pakkalan mandi }\end{array}$ & $\begin{array}{l}\text { Pasal 4: (2) Kenalan } \\
\text { cuncom di iwa-iwa darak } \\
\text { (3) Jengan bersih dibah } \\
\text { dilambung, pakkalan }_{\text {deros }^{5}}\end{array}$ & $\begin{array}{l}\text { atau membelakangi } \\
\text { sungai karena adanya } \\
\text { pekkalan mandi }{ }^{1}\end{array}$ \\
\hline & & $\begin{array}{l}\text { BAB VI Jugul Muda; (17) } \\
\text { Lelaki tidak boleh } \\
\text { mendekati pemandian } \\
\text { wanita }^{6}\end{array}$ & \multirow{2}{*}{$\begin{array}{l}\text { Pekkalan mandi ragah } \\
\text { dan sebai harus } \\
\text { dipisah, tiap lebuh } \\
\text { punya pekkalan } \\
\text { sendiri, tiap pekkalan } \\
\text { mempunyai lanting }{ }^{9}\end{array}$} \\
\hline & & $\begin{array}{l}\text { BAB VIII Mengenai } \\
\text { Perilaku Orang Suami-Istri; } \\
\text { (7) Menyebut perihal } \\
\text { tangga menuju pemandian }{ }^{6}\end{array}$ & \\
\hline Jalan & $\begin{array}{l}\text { Jalan di permukiman pada } \\
\text { umumnya memanjang, } \\
\text { dengan deretan rumah } \\
\text { yang berhadapan }{ }^{1}\end{array}$ & $\begin{array}{l}\text { Pasal 4: (4) Ranglaya } \\
\text { gawang }{ }^{1}\end{array}$ & - \\
\hline \multirow[b]{2}{*}{ Pusiban } & \multirow[b]{2}{*}{-} & $\begin{array}{l}\text { Pasal 2: (5) Mak } \\
\text { ngegantungkon kelepun } 5\end{array}$ & $\begin{array}{l}\text { Pusiban harus } \\
\text { dibangun di samping } \\
\text { sesat }^{9}\end{array}$ \\
\hline & & $\begin{array}{l}\text { BAB VI Jugul Muda; (18) } \\
\text { Pusiban rubuh, ada yang } \\
\text { cidera atau meninggal, } \\
\text { pemilik didenda }^{6}\end{array}$ & $\begin{array}{l}\text { Pusiban bisa dibangun } \\
\text { di ujung atau di tengah } \\
\text { kampung }^{10}\end{array}$ \\
\hline $\begin{array}{l}\text { Tanah } \\
\text { Pemakam } \\
\text { an }\end{array}$ & 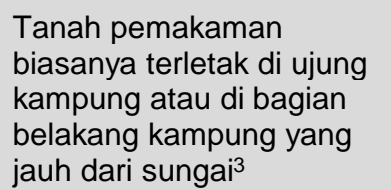 & - & $\begin{array}{l}\text { Pemakaman hampir di } \\
\text { sekeliling tiyuh, setiap } \\
\text { lebuh punya kompleks } \\
\text { makam sendiri,11 }\end{array}$ \\
\hline
\end{tabular}

(Pratiwi \& Gunawan, 2017); ${ }^{2}$ (Proyek Penelitian dan Pencatatan Kebudayaan Daerah, 1978); ${ }^{3}$ (Wahyuningsih, 2011); ${ }^{4}$ (Rusdi et al., 1986); ${ }^{5}$ Kuntara Raja Niti (Bumi Jawa Sukadana); ${ }^{6}$ Kuntara Raja Niti (Penengahan); ${ }^{7}$ Buku Handak II; ${ }^{8}$ Ketaro Abung; ${ }^{9}$ Raden Supardi GIr. Raden Ustad Marga; ${ }^{10}$ Buya Wahid GIr. Tuan Kebudayaan; ${ }^{11}$ Ali Bakri GIr. Kilat Mas; ${ }^{12}$ Firmansyah; ${ }^{13}$ Mat Amin

Ciri khas lain yang biasanya terlihat dalam permukiman tradisional Lampung adalah tidak ada batas yang jelas antar rumah, antar rumah maupun antar rumah dengan jalan biasanya hanya dibatasi oleh ruang terbuka yang dibiarkan kosong. Hal ini ditegaskan dalam Kitab Kuntara Raja Niti (Bumi Jawa Sukadana) Pasal 4 Ganjaran humbul 5 perkara ayat 4 yang mengatur masyarakat untuk selalu menjaga lingkungan rumahnya dan jalan raya di depannya agar selalu bersih. Pada tiyuh umumnya dapat dijumpai pusiban, yakni bangunan berbentuk gubuk berukuran kecil dengan dinding separuh yang biasanya dijadikan sebagai tempat bersantai dan juga tempat berjaga malam. Pusiban ini bisa merupakan milik individu atau milik bersama di dalam tiyuh. Hal ini ditegaskan dalam Kitab Kuntara Raja Niti (Bumi Jawa Sukadana) Pasal 2 Maluni tiyuh 10 perkara ayat 5. Maksud dari ayat ini adalah jika dalam suatu tiyuh tidak digantungkan kentongan di pusibannya, maka artinya tidak ada kegiatan berjaga malam yang dilakukan oleh masyarakat sehingga keamanan tiyuh tidak terjaga. Menjaga pusiban sebagaimana menjaga bangunan lain di dalam tiyuh adalah suatu kewajiban bagi masyarakatnya. Hal ini tertulis dalam Kitab Kuntara Raja Niti 
(Penengahan) Bab VI Jugul Muda pasal 18, yang mengharuskan masyarakat untuk memelihara pusiban, baik milik pribadi atau milik bersama.

Lokasi tiyuh yang umumnya selalu berada di dekat sungai memengaruhi letak lokasi tanah pemakaman. Umumnya pemakaman berada jauh dari permukiman, terletak di bagian belakang dan masuk ke dalam hutan. Hal ini dilakukan untuk mengantisipasi air sungai yang bisa naik jika terjadi hujan, jika makam berada di bawah dikhawatirkan akan merusak makam. Perbedaan kelompok lebuh pada Tiyuh Gedung Batin memengaruhi lokasi pemakaman. Masing-masing lebuh memiliki area pemakaman masing-masing. Meskipun telah ada pemakaman umum baru, anggota lebuh masih memilih untuk menggunakan makam kelompok mereka. Makam lama dari keluarga Lebuh Tengah berada terpisah dari permukiman, karena berada di posisi Tiyuh Gedung Batin yang lama.

\section{DISKUSI DAN PEMBAHASAN}

Bentuk Tiyuh Gedung Batin tergolong ke dalam tipe pola permukiman yang berbentuk memanjang (Ari dkk., 2005, hlm. 79), dengan bentuk permukiman yang memusat (agglomerated rural settlement) berupa hamlet atau dusun dengan rumah-rumah yang berjumlah kurang dari 40 (Jayadinata, 1999, hlm. 43). Pola permukiman tradisional tiyuh Lampung yang memanjang mengikuti sungai ini juga sesuai dengan pendapat Leibo (1995, hlm. 9) yakni salah satu bentuk permukiman di perdesaan adalah line village. Pola ini juga merupakan bentuk adaptasi terhadap lingkungan karena sebelum ada kemudahan transportasi darat, semua kegiatan masyarakat dilakukan dari dan melalui sungai. Karakter suatu lanskap akan terbentuk dari interaksi manusia dengan lingkungannya (Atik dkk., 2015, hlm. 90). Hal inilah yang pada akhirnya memberikan ciri kepada permukiman tradisional Lampung yang sebagian besar berbentuk memanjang mengikuti aliran sungai.

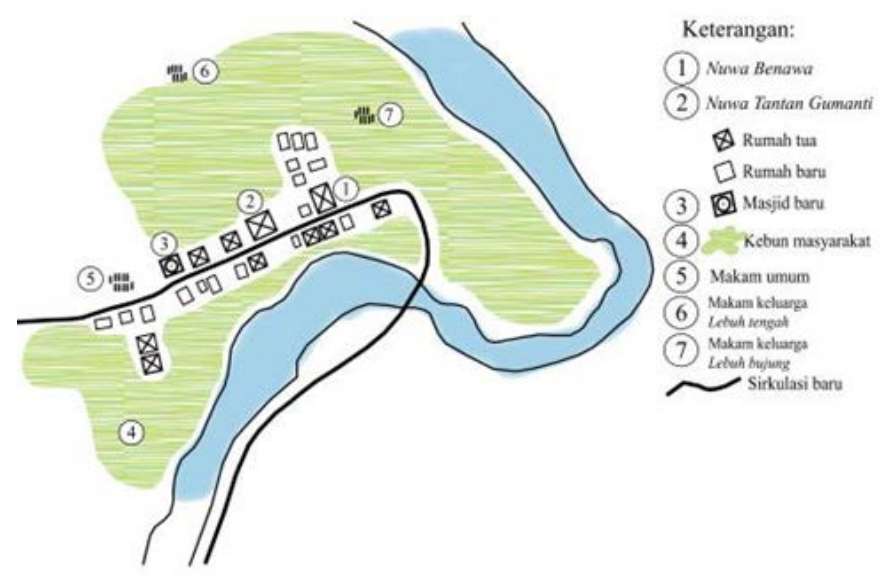

Gambar 6. Pola Permukiman Tradisional Tiyuh Gedung Batin Saat Ini (Sumber :Penulis)

Elemen-elemen penyusun permukiman berada di dalam ruang-ruang yang membentuk pola permukiman secara keseluruhan. Berdasarkan sifatnya, 
ruang permukiman dapat dibagi menjadi ruang publik, ruang semi publik, dan ruang privat (Booth, 1990, hlm. 163). Ruang publik adalah ruang yang dapat diakses oleh semua orang, yang termasuk elemen dalam ruang publik antara lain adalah bangunan komunal, tempat ibadah, jalan permukiman, serta pakkalan mandi. Ruang privat adalah ruang yang hanya dapat diakses oleh pemilik, yang termasuk elemen dalam ruang privat adalah rumah tinggal beserta ruang di sekitarnya. Ruang semi publik adalah ruang yang bersifat setengah publik di mana semua orang dapat mengaksesnya namun dalam kondisi tertentu ruang ini tidak dapat digunakan.

Elemen permukiman yang termasuk dalam ruang ini adalah tanah pemakaman. Pola permukiman tradisional Tiyuh Gedung Batin saat ini dapat dilihat pada Gambar 6, sementara pola permukiman tradisional Tiyuh Gedung Batin serta tata letak elemen-elemen yang seharusnya menurut ada menurut budaya dapat dilihat pada Gambar 7. Lanskap permukiman Tiyuh Gedung Batin dibentuk oleh tiga faktor dominan yaitu faktor strata sosial, faktor kekerabatan, dan faktor lingkungan. Pola spasial permukiman tidak hanya ditentukan dari kegiatan sehari-hari masyarakatnya namun juga oleh norma-norma sosial yang berlaku (Nunta dkk., 2010, hlm. 1242). Strata sosial di Tiyuh Gedung Batin dalam hal kedudukan pemangku adat dan masyarakat biasa terlihat dengan jelas. Kedudukan tertinggi di tiyuh dipegang oleh punyimbang marga, kedudukan kedua adalah punyimbang tiyuh, kedudukan selanjutnya adalah cempana patih kuning dan masyarakat biasa. Strata sosial ini memengaruhi bentuk dan tipe rumah dalam permukiman.

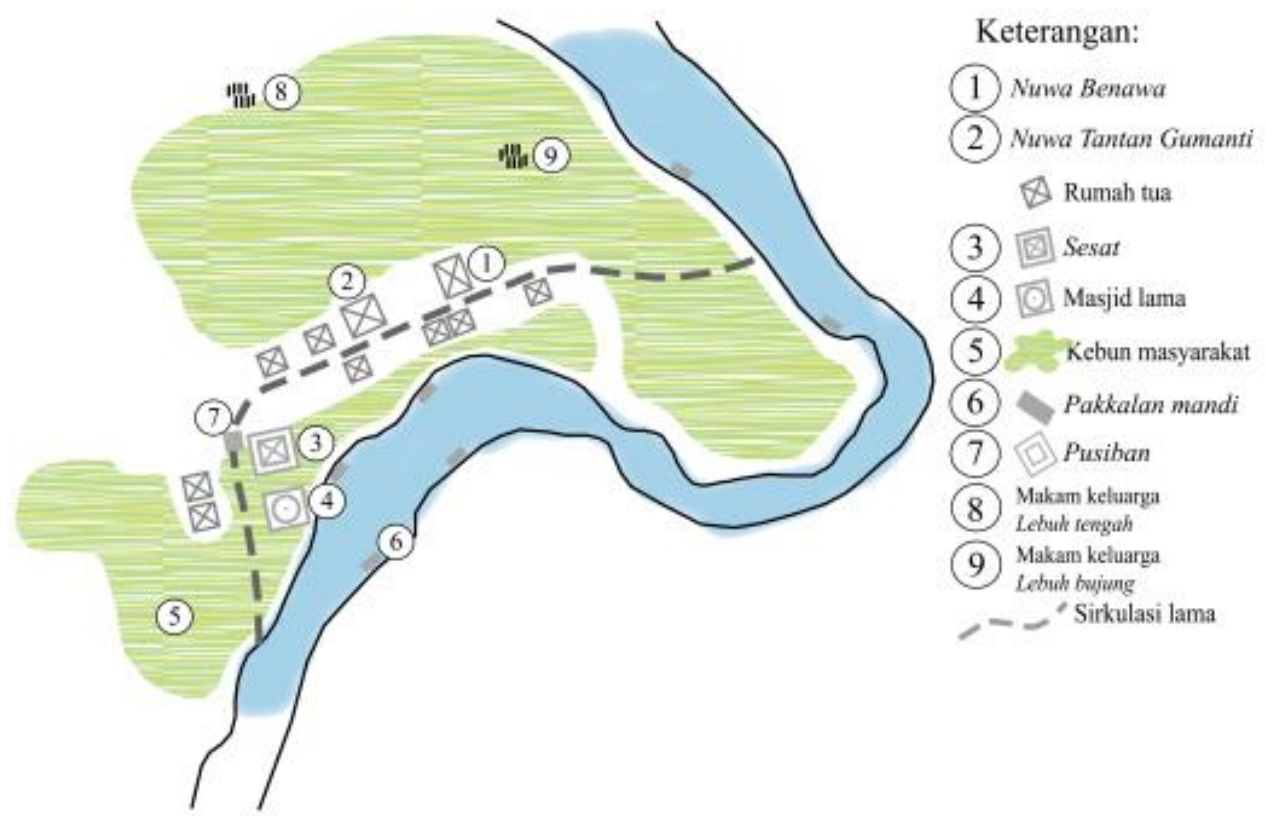

Gambar 7. Pola Permukiman Tradisional Tiyuh Gedung Batin Serta Tata Letak Elemen-Elemen Menurut Budaya

(Sumber :Penulis) 
Faktor kekerabatan merupakan faktor pembentuk permukiman tradisional yang paling dominan. Penataan rumah-rumah dalam permukiman didasarkan pada hubungan kekerabatan dalam hal ini adalah hubungan antar lebuh. Tidak ada aturan khusus yang mengatur anggota dari masing-masing lebuh untuk membangun rumah di dekat rumah pemimpinnya. Anggota dari masing-masing lebuh hidup berbaur. Tiyuh Gedung Batin telah mengalami beberapa kali perpindahan lokasi. Perpindahan lokasi ini dikarenakan lokasi awal kampung sering terkena banjir. Meskipun telah berpindah, tiyuh tetap dibangun dekat dengan aliran sungai karena mempertimbangkan alasan efisiensi pergerakan dan transportasi. Sebelum dibangunnya jalan dan jembatan, semua kegiatan transportasi dilakukan melalui aliran sungai.

\section{KESIMPULAN}

Tiyuh Gedung Batin dibentuk oleh rumah-rumah tua dan rumah baru di sekitarnya, sebagian kebun warga di sekitar rumah, jalan utama yang memanjang membelah tiyuh, serta sungai Way Besai. Tiyuh Gedung Batin merupakan kampung lebuh (kerajaan) di mana pada masa itu ada tiga lebuh yang memimpin di tiyuh yakni Lebuh Bujung, Lebuh Tengah, dan Lebuh Talang. Pada perkembangannya, Lebuh Bujung membagi keturunannya untuk membentuk Lebuh Bujung Unggak. Elemen permukiman tradisional Lampung Pepadun terdiri dari bangunan tradisional (rumah tinggal, bangunan komunal (sesat), serta tempat ibadah), lahan garapan, sungai, jalan permukiman serta tanah pemakaman. Tiyuh Gedung Batin tersusun dalam pola yang memanjang mengikuti aliran sungai dengan rumah-rumah yang saling berhadapan. Rumah-rumah berbaris dan umumnya antar rumah tidak memiliki batas yang jelas karena hubungan kekeluargaan yang erat. Pola ini merupakan bentuk adaptasi terhadap lingkungan, di mana menurut sejarah masyarakat Lampung Pepadun umumnya bermukim di pedalaman dan berpindah mengikuti aliran sungai. Sebelum adanya jalan raya dan jembatan, semua aktivitas perpindahan dilakukan melalui sungai. Faktor dominan yang memengaruhi pembentukan lanskap permukiman tradisional Lampung adalah faktor strata sosial, kekerabatan, dan lingkungan.

\section{SARAN/ REKOMENDASI}

Tiyuh Gedung Batin di Kecamatan Blambangan Umpu, Provinsi Lampung memiliki potensi sebagai cagar budaya, sehingga diperlukan upaya perlindungan dalam pengembangan dan pemanfaatannya. Pertumbuhan penduduk lokal dan potensi tyuh yang menarik wisatawan selain memberi dampak positif dalam pengembangan kawasan, juga membawa dampak negatif seperti bergesernya nilai budaya asli tiyuh. Usaha pengembangan kawasan sebaiknya melibatkan pemerintah setempat, ahli, serta masyarakat sekitar sehingga potensi dari tiyuh dapat dikembangkan dengan tanpa merusak atau merubah nilai budaya asli dari tiyuh. 


\section{UCAPAN TERIMA KASIH}

Penulis mengucapkan terima kasih kepada Radin Supardi selaku Punyimbang Marga Lebuh Tengah yang telah memberikan akomodasi selama penelitian, Ali Bakri Gelar Kilat Mas selaku Punyimbang Marga Lebuh Bujung serta kepada para Punyimbang Tiyuh atas bantuannya selama penelitian. Balai Pelestarian Nilai Budaya Jawa Barat serta seluruh pihak yang telah membantu penulis dalam penyelesaian artikel ini. Penulis juga mengucapkan terima kasih kepada Drs. T. Dibyo Harsono, M.Hum, selaku Staff Peneliti Budaya Lampung Balai Pelestarian Nilai Budaya Jawa Barat yang telah membantu dalam proses validasi data, serta kepada seluruh pihak yang telah membantu penulis dalam penyelesaian artikel ini. 


\section{DAFTAR PUSTAKA}

Antariksa. (2011). Pola Permukiman Tradisional. https://doi.org/10.24832/kapata.v12i2.310

Atik, M., Işikli, R. C., Ortaçeşme, V., \& Yildirim, E. (2015). Definition of landscape character areas and types in Side region, Antalya-Turkey with regard to land use planning. Land Use Policy, 44, 90-100. https://doi.org/10.1016/j.landusepol.2014.11.019

Booth, N. K. (1990). Basic Elements of Landscape Architectural Design. New York: Waveland Press.

Crysler, C. G. (2000). Writing Spaces: Cultural Translation and Critical Reflexivity in Traditional Dwellings and Settlements Review. Traditional Dwellings and Settlements Review, 11(2), 51-59.

Djaelani, A. R. (2014). Teknik Pengumpulan Data dalam Penelitian Kualitatif. Majalah Ilmiah Pawiyatan, 20(1), 82-92.

Doxiadis, C. A. (1970). Ekistics, the Science of Human Settlements. Science, 170(3956), 393-404. Retrieved from http://www.sciencemag.org/cgi/content/citation/170/3956/393

Hadikusuma, H. (1989). Masyarakat dan Adat Budaya Lampung (Cetakan Pe). Bandung: Mandar Maju.

Ingold, T. (1993). Temporality of the Landscape. World Archaeology, 25(2), 152-174. Retrieved from doi:10.1080/00438243.1993.9980235

Jayadinata, J. T. (1999). Tata Guna Tanah dalam Perencanaan Pedesaan Perkotaan dan Wilayah. Bandung: ITB.

Krisna, R., Antariksa, \& Ari, I. R. D. (2005). Studi Pelestarian Kawasan Wisata Budaya Di Dusun Sade. Jurnal Plannit, 3(2), 124-133.

Leibo, J. (1995). Sosiologi Pedesaan (Edisi Kedu). Yogyakarta: Andi.

Lune, H., \& Berg, B. L. (2017). Methods for the Social Sciences Global Edition (Ninth Edit). Boston: Pearson.

Miles, M. B., \& Huberman, A. M. (2007). Analisis Data Kualitatif: Buku Sumber Tentang Metode-metode Baru. Jakarta: UI-Press. 
Nunta, J., \& Sahachaisaeree, N. (2010). Determinant of cultural heritage on the spatial setting of cultural landscape: A case study on the northern region of Thailand. Procedia - Social and Behavioral Sciences, 5, 1241-1245. https://doi.org/10.1016/j.sbspro.2010.07.268

Pinke, Z., Ferenczi, L., Gábris, G., \& Nagy, B. (2016). Settlement patterns as indicators of water level rising? Case study on the wetlands of the Great Hungarian Plain. Quaternary International, 415, 204-215. https://doi.org/10.1016/j.quaint.2015.11.032

Pratiwi, R. A., \& Gunawan, A. (2017). Study of Lampungnese Traditional Home Garden Design. IOP Conference Series: Earth and Environmental Science, 91(1), 1-8. https://doi.org/10.1088/1755-1315/91/1/012024

Proyek Penelitian dan Pencatatan Kebudayaan Daerah. (1978). Adat Istiadat Daerah Lampung. Jakarta: Departemen Pendidikan dan Kebudayaan, Pusat Penelitian Sejarah dan Budaya.

Rini Dwi Ari, I., \& Antariksa. (2005). Studi Karakteristik Pola Permukiman Di Kecamatan Labang, Madura. Jurnal ASPI, 4(2), 78-93.

Rusdi, U., Arifin, R., Suparno, Indra, W. D., \& Zaini, F. (1986). Arsitektur Tradisional Daerah Lampung (R. Abu, Ed.). Jakarta: Departemen Pendidikan dan Kebudayaan, Proyek Inventarisasi dan Dokumentasi Kebudayaan Daerah.

Sulasman. (2014). Metodologi Penelitian Sejarah; Teori, Metode, Contoh Aplikasi (T. Arifin, Ed.). Bandung: Pustaka Setia.

Wahyuningsih, E. (2011). Arsitektur Tradisional Daerah Lampung. Jakarta: Kementerian Kebudayaan dan Pariwisata, Direktorat Jenderal Nilai Budaya, Seni, dan Film, Direktorat Tradisi.

\section{Daftar Narasumber}

1. Radin Supardi, Punyimbang marga, pemilik Nuwa (rumah) Tantan Gumanti

2. Ali Bakri Glr. Kilat Mas, Punyimbang marga, pemilik Nuwa (rumah) Benawa

3. Buya Wahid Glr. Tuan Kebudayaan, Punyimbang tiyuh

4. Mastura, Pemilik Nuwa Benawa

5. Firmansyah, Penghulu Tiyuh Gedung Batin

6. Mat Amin, Warga Tiyuh Gedung Batin

7. Rajamin, Warga Tiyuh Gedung Batin

8. Drs. T. Dibyo Harsono, M.Hum, Staf Peneliti Budaya Lampung, BPNB 
